\title{
Reproduction and demographic trends of Sula Leucogaster at the Moleques do Sul Archipelago, Santa Catarina, Brazil
}

\author{
Joaquim Olinto Branco ${ }^{1}$, Hélio Augusto Alves Fracasso ${ }^{2,4}$ \& Valéria dos Santos Moraes-Ornellas ${ }^{3}$ \\ ${ }^{1}$ Centro de Ensino em Ciências Tecnológicas da Terra e do Mar, Universidade do Vale do Itajaí-UNIVALI, \\ CP 360, CEP 88301-970, Itajai, SC, Brasil \\ ${ }^{2}$ Laboratório de Ecologia do Meiobentos Marinho, Instituto Oceanográfico, Universidade de São Paulo - USP, \\ CEP 05508-120, São Paulo, SP, Brasil \\ ${ }^{3}$ Laboratório de Ornitologia, Universidade Federal do Rio de Janeiro - UFRJ, Ilha do Fundão, \\ CEP 21.941-590, Rio de Janeiro, RJ, Brasil \\ ${ }^{4}$ Corresponding author: Hélio Augusto Alves Fracasso, e-mail: h_fracasso@yahoo.com.br
}

BRANCO, J.O., FRACASSO, H.A.A. \& MORAES-ORNELLAS, V.S. Reproduction and demographic trends of Sula Leucogaster at the Moleques do Sul Archipelago, Santa Catarina, Brazil. Biota Neotrop. 13(4): http:// www.biotaneotropica.org.br/v13n4/en/abstract?article+bn00713042013

\begin{abstract}
The Brown Booby, Sula Leucogaster, is one of the most common species of marine birds of the Brazilian coast and, in spite of being a viable subject for long-term studies, in Brazil there are scarce demographic descriptions of this species obtained from observations made in sets of consecutive years. This paper presents breeding information collected in monthly samples taken in the Moleques do Sul Island, Florianópolis, Santa Catarina, during a five year period. The main island was divided into three different study areas, in which adult censuses were conducted, along with counts of number of nests, eggs, chicks and incubating adults. No significant change was found in these numbers during the sampled years and the breeding season extended over the entire year, with a peak production of eggs and chicks from August to November. The flatter areas II and I were preferentially used, where a higher number of nests with two eggs were found. A certain number of individuals abandoned the colony outside the breeding season during some of the sampled years, which may be related to an alternation between abandonment and permanence, non-exclusive phenomena possibly associated with food availability and favorable environmental conditions. The long term knowledge of the demographic patterns and of occupation parameters of this Brown Bobby colony is essential for the conservation of the species and its habitats.
\end{abstract}

Keywords: Brown Booby, reproduction, demographic parameters, Santa Catarina, Brazil.

BRANCO, J.O., FRACASSO, H.A.A. \& MORAES-ORNELLAS, V.S. Reprodução e tendências demográficas do atobá-pardo (Sula Leucogaster) no Arquipélago de Moleques do Sul, Santa Catarina, Brasil. Biota Neotrop. 13(4): http://www.biotaneotropica.org.br/v13n3/pt/abstract?article+bn00713042013

Resumo: O atobá-pardo, Sula Leucogaster, é uma das espécies mais comuns de aves marinhas do litoral brasileiro e, apesar de passível a ser objeto de estudos de longo-termo, no Brasil há escassas descrições de aspectos da demografia da espécie obtidas a partir de observações realizadas em conjuntos de anos consecutivos. O presente trabalho fornece informações sobre sua reprodução coletadas em amostragens mensais realizadas na Ilha Moleques do Sul, Florianópolis, SC, em um período de cinco anos. A ilha foi subdividida em três diferentes áreas de estudo, onde foram realizados censos de adultos e contagem do número de ninhos, ovos, filhotes e adultos incubando. Verificou-se que não houve alteração significativa dos números nos anos amostrados, com a temporada reprodutiva se estendendo ao longo de todo ano e pico de postura de agosto a novembro. As áreas II e I, mais planas, foram utilizadas preferencialmente e encontrou-se maior número de ninhos com dois ovos. Houve abandono da colônia por certo número de indivíduos fora do período reprodutivo em alguns dos anos amostrados, o que pode estar relacionado a uma alternância entre abandono e permanência, fenômenos não excludentes possivelmente associados à disponibilidade de alimento e condições ambientais favoráveis. A população do atobá-pardo que nidifica na Ilha Moleques do Sul está em equilíbrio, não sofrendo alterações no contingente reprodutivo ao longo dos anos. $\mathrm{O}$ conhecimento dos padrões demográficos e de ocupação da colônia a longo termo é essencial para a conservação das espécies e habitats envolvidos.

Palavras-chave: Atobá-Pardo, reprodução, parâmetros demográficos, Santa Catarina, Brasil. 


\section{Introduction}

The Brown Booby, Sula leucogaster (Boddaert 1783), has a geographic distribution within the tropical oceans, stretching between the latitudes of $30^{\circ} \mathrm{N}$ and $30^{\circ} \mathrm{S}$ (Marchant \& Higgins 1990). This Booby is considered to be one of the most common marine bird species along the Brazilian Coast and, although Sick (1997) has estimated its population in about 5.000 individuals, currently its population is known to be much bigger. In the Currais Archipelago, Paraná, Krul (2004) observed an approximate number of 2,800 individuals, between the months of February and May. Neves (1999) cites 2,000 individuals on the Laje de Santos and Campos et al. (2004) counted 800 individuals on Castilho Island, both these colonies are located along the São Paulo Coast. Large populations of S. leucogaster also inhabit islands off the Rio de Janeiro Coast (Alves et al. 2004a) and the Abrolhos Archipelago, Bahia (Alves et al. 1997, 2004b). Smaller populations are recorded from the Fernando de Noronha Archipelago and the Atol das Rocas (Schulz-Neto 2004a, b), and from the São Pedro and São Paulo Archipelago (Both \& Freitas 2004). In Santa Catarina, reproduction has been confirmed in the Tamboretes (Branco 2003), Baía da Babitonga (Grose et al. 2011) and Moleques do Sul Archipelago, representing the southern distribution limit of the species (Bege \& Pauli 1989, Branco et al. 2005).

The Brown Booby shows easily identified sexual dimorphism, which, according to Lewis et al. (2005), extends to the differential selection of feeding sites. The females make shorter trips and are more active in defending the nests, while males are smaller and more agile, make longer trips and are best suited to provide food for the nestlings. However, Tershy \& Croll (2000) concluded that females are responsible for delivering a greater proportion of food to offspring, than males. The species breeds continuously and desynchronized, although reproductive peaks are observed (Alves et al. 1997, Branco 2004). The nests are made on the ground with sticks, dry leaves, feathers and sometimes man-made material (Martins \& Dias 2003, Coelho et al. 2004). Usually two eggs are laid which are incubated in alternating shifts during 42 to 45 days (Dorward, 1962, Sick 1997). This is a species that has a long life span, slow growth and low fecundity, and, is therefore, a viable subject of long-term studies (Beadell et al. 2003). In Brazil, only Branco et al. (2010) describes the demography of the species from observations made during a number of consecutive years in the Moleques do Sul Islands, Santa Catarina.

The present study provides additional information about the reproduction of the Brown Booby colony in Moleques do Sul Island. The data is analyzed to verify the occurrence of changes in population size during five years and if there is a preference for particular types of nesting substrates. Aspects of colony fidelity and demographic patterns that characterize the presence of the species on the island are discussed.

\section{Material and Methods}

Samples were taken monthly in the Moleques do Sul Islands, Florianopolis, Santa Catarina $\left(27^{\circ} 51^{\prime} \mathrm{S}, 48^{\circ} 26^{\prime} \mathrm{W}\right)$ during the period from January 2002 to December 2007, except during July, 2002, 2004 and 2007 and December 2003, 2004 and 2006. The main island of the Moleques do Sul Archipelago (Figure 1) was subdivided into three different study areas of the same size $\left(\mathrm{m}^{2}\right)$, with areas I and II located on the west side and exposed mainly to NE and SE winds; and area III in the area facing the east side, under greater influence of the N and NW winds. The area I consists of a steeply inclined slope going from the high tide mark, through creeping grass and small rocky outcrops, up to the bushes. The area II is dominated by bare soil, conglomerate rocks and small bushy areas, while area III is predominantly characterized by a mixture of bare soil and rocks, surrounded by bushes and a large ravine.

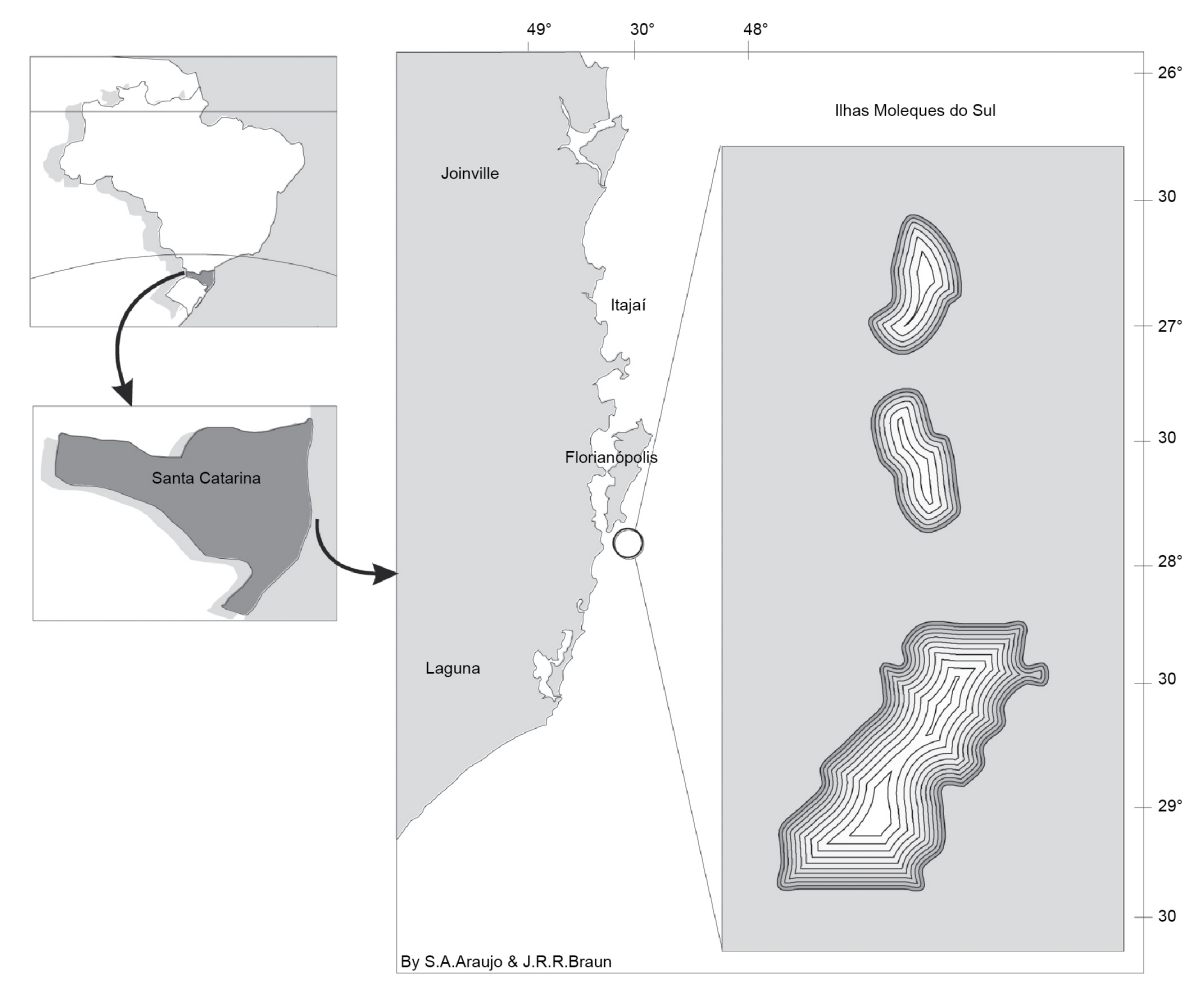

Figure 1. Map of sampling site, Moleques do Sul Island showing the main island. 
Censuses of Sula leucogaster were conducted, including counts of the number of nests, eggs / nest, chicks and incubating adults. The nestlings were captured with hands or dip nets and classified according to their plumage, following Dorward (1962), and culmen length categories (measured by the culmen nozzle was measured from the tip to the base, Table 1). The variance of the number of nests, young and adults between years and within study areas, was examined using a fixed ANOVA (Sokal \& Rohlf 1969). The homogeneity of variance was analyzed using the Kolmogorov-Smirnov test, while the Tukey-Kramer test was applied to the occurrence of different statistics $(\mathrm{p}<0.05)$, to indicate which mean values were significantly different.

\section{Results}

Two peaks in abundance of breeding adults were observed at the site, the first in January and February, and the second from August to November, with significant differences $\left(\mathrm{F}_{11,54=} 2.631, \mathrm{p}<0.01\right)$ between the months of January (higher) and May (lower) (Table 2). The largest total numbers of adults occurred in the 2002, 2005 and 2007 seasons, and the lowest in 2003 and 2004, with no significant difference between the sampled years $\left(\mathrm{F}_{5,66}=0.1177, \mathrm{p}<0.05\right)$. The number of incubating adults also showed no significant differences over the sample period during the years of study $\left(\mathrm{F}_{11,24}=0.8920\right.$, $\mathrm{p}>0.05)$. However, they were significantly more abundant in areas I and II than in area III $\left(\mathrm{F}_{2,33}=23.377, \mathrm{p}<0.05\right)$ (Figure 2).
From January to July there was a gradual decrease in the number of incubating adults, nests and chicks, increasing up to the peak in October / November (Figure 2). The reproductive season extended throughout the year and the peak production occurred between August and November with a significant difference in the number of nests $\left(F_{11,47=9.573, p}<0.0001\right)$. The contrast between the values of the peak and the period from May to July was the source of variation. No significant difference $\left(\mathrm{F}_{5,53}=0.622, \mathrm{p}>0.05\right)$ was observed in the total number of nests over the years, although the largest number was recorded in 2002 and the lowest in 2004 (Table 2).

The number of nests was significantly different within the months during the sampled years $\left(\mathrm{F}_{11,24=} 2.497, \mathrm{p}<0.05\right)$ and within sampled areas $\left(\mathrm{F}_{2,33} 4.873, \mathrm{p}<0.05\right)$. The contrast between the higher values in area II than in area III was the cause of the variation (Figure 2). The number of young did not change significantly over the months and years $\left(\mathrm{F}_{11,24=} 1.540, \mathrm{p}>0.05\right)$, but in 2002 and 2005 the number of young was significantly higher $\left(\mathrm{F}_{5,60} 2.546, \mathrm{p}<0,05\right)$ than in 2006 (Table 4). There was also a significant difference $\left(\mathrm{F}_{11,53=} 3.883\right.$, $\mathrm{p}<0.001)$ between the highest numbers in January and November and the lowest in June and July (Table 1 and 2), more young being found in areas II and III than in area $\mathrm{I}\left(\mathrm{F}_{2,33}=12.611, \mathrm{p}<0.0001\right)$ (Figure 2).

We found that $64.3 \%$ of the nests contained two eggs and $35.5 \%$ and $0.2 \%$, one and three eggs, respectively. A larger number of nests were concentrated in area II, followed by areas I and III, except during

Table 1. Classification of young S. leucogaster according to their plumage (following Dorward, 1962) and to culmen length categories.

\begin{tabular}{|c|c|c|c|}
\hline Stage & Age (days) & General Characteristics & $\begin{array}{l}\text { Culmen } \\
\text { Length }\end{array}$ \\
\hline Young I & $1-13$ & Devoid of feathers & 1.0 to $3.1 \mathrm{~cm}$ \\
\hline Young II & $14-36$ & Covered with white feathers & 2.9 to $6.6 \mathrm{~cm}$ \\
\hline Young III & $37-60$ & Visible remiges and rectrices feathers & 6.7 to $9.6 \mathrm{~cm}$ \\
\hline Young IV & $85-105$ & Completely feathered or with traces of feathers on the head, neck and flanks & 8.2 to $10.2 \mathrm{~cm}$ \\
\hline Juvenile & 120 & Brown feathered and able to fly & 8.4 to $10.6 \mathrm{~cm}$ \\
\hline
\end{tabular}

Table 2. Monthly distribution of the total number of adults, chicks and nests of S. leucogaster during the 2002 to 2007 reproductive seasons, in the Moleques do Sul Islands.

\begin{tabular}{|c|c|c|c|c|c|c|c|c|c|c|c|c|c|c|}
\hline Year & $\mathbf{N}$ & $\mathbf{J}$ & $\mathbf{F}$ & $\mathbf{M}$ & $\mathbf{A}$ & $\mathbf{M}$ & $\mathbf{J}$ & $\mathbf{J}$ & A & $\mathbf{S}$ & $\mathbf{O}$ & $\mathbf{N}$ & D & Total \\
\hline \multirow{3}{*}{2002} & adults & 933 & 464 & 516 & 798 & 87 & 412 & - & 1525 & 433 & 526 & 565 & 490 & 6749 \\
\hline & nests & - & 3 & 1 & 1 & - & 4 & - & 426 & 192 & 80 & 129 & 80 & 916 \\
\hline & chicks & 171 & 173 & 117 & 97 & 181 & 10 & - & 14 & 51 & 115 & 204 & 241 & 1374 \\
\hline \multirow{3}{*}{2003} & adults & 593 & 828 & 344 & 200 & 302 & 129 & 236 & 262 & 364 & 630 & 513 & - & 4401 \\
\hline & nests & - & 1 & 4 & - & - & - & 90 & 149 & 166 & 201 & 175 & - & 786 \\
\hline & chicks & 125 & 88 & 67 & 54 & 41 & 29 & 16 & 40 & 72 & 103 & 136 & - & 771 \\
\hline \multirow{3}{*}{2004} & adults & 924 & 584 & 263 & 145 & 168 & 181 & - & 332 & 557 & 413 & 744 & - & 4311 \\
\hline & nests & 10 & 5 & 2 & 2 & 3 & 2 & - & 30 & 158 & 124 & 121 & - & 457 \\
\hline & chicks & 131 & 35 & 70 & 42 & 37 & 12 & - & 2 & 100 & 117 & 212 & - & 758 \\
\hline \multirow{3}{*}{2005} & adults & 430 & 430 & 443 & 417 & 431 & 548 & 493 & 357 & 429 & 564 & 539 & 929 & 6010 \\
\hline & nests & - & 14 & 15 & 19 & 16 & 46 & 167 & 102 & 130 & 161 & 125 & 50 & 845 \\
\hline & chicks & 154 & 218 & 74 & 142 & 135 & 25 & 30 & 157 & 102 & 109 & 94 & 140 & 1380 \\
\hline \multirow{3}{*}{2006} & adults & 965 & 544 & 218 & 303 & 233 & 355 & 252 & 467 & 398 & 708 & 433 & - & 4876 \\
\hline & nests & 28 & 15 & 4 & 1 & 2 & 16 & 170 & 178 & 125 & 190 & 129 & - & 858 \\
\hline & chicks & 128 & 86 & 77 & 59 & 29 & 14 & 15 & 41 & 97 & 55 & 58 & - & 659 \\
\hline \multirow{3}{*}{2007} & adults & 898 & 703 & 537 & 385 & 336 & 605 & - & 565 & 435 & 600 & 551 & 155 & 5770 \\
\hline & nests & 9 & 43 & 47 & 24 & 9 & 21 & - & 306 & 115 & 120 & 95 & 16 & 805 \\
\hline & chicks & 146 & 113 & 131 & 103 & 65 & 58 & - & 17 & 95 & 88 & 138 & 39 & 993 \\
\hline \multirow{3}{*}{ Total } & adults & 4743 & 3553 & 2321 & 2248 & 1557 & 2230 & 981 & 3508 & 2616 & 3441 & 3345 & 1574 & 32117 \\
\hline & nests & 47 & 81 & 73 & 47 & 30 & 89 & 427 & 1191 & 886 & 876 & 774 & 146 & 4667 \\
\hline & chicks & 855 & 713 & 536 & 497 & 488 & 148 & 61 & 271 & 517 & 587 & 842 & 420 & 5935 \\
\hline
\end{tabular}



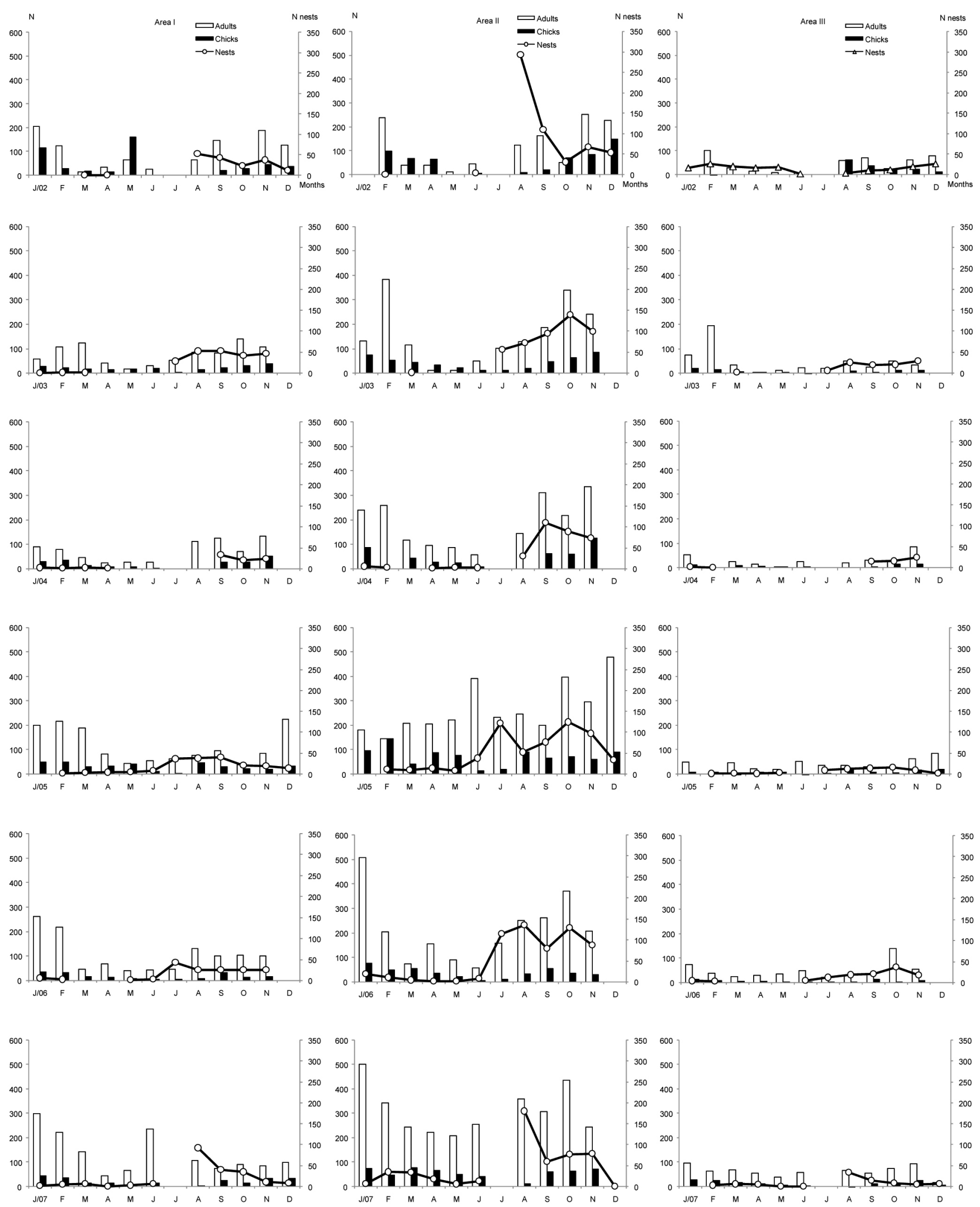

Figure 2. Monthly abundance of adults in breeding activity, nests and chicks of S. leucogaster in three areas during the 2002 to 2007 seasons on the Moleques do Sul Islands. 
2004 and 2006 when area III had the highest concentration of nests. The number of chicks followed the same trend as the nests, with respect to number per area, where $32.1 \%$ were juveniles followed by young III (31.3\%), II (15.1\%), I (11.9\%) and IV (9.6\%), respectively (Table 3). The year 2007 was somewhat atypical for the occurrence of juveniles because chicks were not observed in January, September and October. We did not notice any numerical synchronism in the sequence of age classes during sequential months. The number of individuals which should pass from one phase to another during the period of two or three months was noticeably different than expected (Table 4).

\section{Discussion}

Despite the breeding peaks which were shown during the present study, the annual total number of adults, nests, and chicks recorded in the Moleques do Sul Islands did not change significantly. However, the years 2002 and 2005 had the largest numbers of adults, nests and chicks, which may be related to periods of favorable environmental conditions. In general, along the Brazilian Coast, the Brown Booby tends to breed continuously, although peaks of reproduction can be observed. Borsa et al. (2010) suggest that the advantages of reproductive seasonality may be the prevention of parasite epidemics and reduction of exposure to predators. On the other hand, the existence of well-defined reproduction peaks may reflect greater prey availability and more appropriate climatic conditions. In Abrolhos, Bahia, most nests with eggs occur between March and July (Alves et al. 1997), in São Paulo from May to October (Campos et al. 2004), along the Parana Coast from February to May (Krul 2004), on Baía da Babitonga, São Francisco do Sul from June to October (Grose et al. 2011) and on the Moleques do Sul Islands, as the results indicate, from August to November. It is clear that there is a predominance of peaks during the autumn and winter months, with smaller numbers of nesting adults, eggs and chicks in the summer months, with the exception of the state of Parana. The adult population average number increased $160 \%$ from a year to another (March) on a rest site in Franceses Island (ES), while the young population remained almost constant (Schuler \& Pinheiro 2009).

There was a predominance of breeding activity in areas I and II, in contrast to decreased use of area III, suggesting that the winds and the proximity of shrubs and trees (substrate for predators) directly affect their occupation of the site. According to Chaves-Campos \& Torres (2002), Brown Boobies may give preference to the occupation of more flat or slightly inclined areas, in the absence of interspecific competition, or for the safety of young and/or for a greater facility to fly. In Cabo Blanco, Costa Rica, the authors noted the Boobies preferred to nest in flat areas, which is corroborated by the findings from this study.

There are two hypotheses which explain the colony occupation patterns: one of them suggests that individuals defend the territories of their nests even outside the reproductive period and the other suggests that the occupation of the colonies occurs only during breeding period. On the Moleques do Sul Islands some Boobies left the colony outside the breeding season during some of the sampled years, which was evidenced by the fact that a lower number of adults were present between the months of May and July in 2002 and 2004. However, in previous research, Branco et al. (2010) observed the occurrence of site fidelity for breeding, as described by Nelson (1978), which corroborates that found by Chaves-Campos \& Torres (2002) regarding the permanence of species in the colonies during non-breeding periods. On Cabo Blanco Island, Boobies are present throughout the year (Chaves-Campos \& Torres 2002), while in Ascension Island they are usually absent outside the reproductive period (Dorward, 1962), as well as in islands in New Zealand (Powlesland \& Powlesland 1993).

The predisposition and philopatry for emigration in S. leucogaster is a widely accepted fact (Beadell et al. 2003). Baumgarten et al. (2001) even consider that perhaps the low genetic variability detected in Boobies could be a consequence of endogamy resulting from the philopatric pattern of the species. However, Branco et al. (2010) recorded only $1.97 \%$ fidelity for Boobies which were marked on the Moleques do Sul Islands between June 2000 and December

Table 3. Number of nests with two and three eggs, Young I, II, III and IV and juvenile S. leucogaster in the three study areas during the 2002 to 2007 reproductive seasons on the Moleques do Sul Islands.

\begin{tabular}{|c|c|c|c|c|c|c|c|c|c|c|c|}
\hline Years & Area & $\mathrm{C1}$ & $\mathrm{C2}$ & $\mathrm{C3}$ & TOTAL & JI & JII & JIII & JIV & Juv & TOTAL \\
\hline \multirow{3}{*}{2002} & I & 70 & 102 & 2 & 174 & 50 & 39 & 119 & 53 & 213 & 474 \\
\hline & II & 159 & 401 & 0 & 560 & 72 & 116 & 221 & 51 & 121 & 581 \\
\hline & III & 62 & 101 & 0 & 163 & 18 & 25 & 70 & 16 & 49 & 178 \\
\hline \multirow{3}{*}{2003} & I & 81 & 135 & 0 & 216 & 35 & 31 & 57 & 19 & 83 & 225 \\
\hline & II & 160 & 280 & 2 & 442 & 93 & 74 & 119 & 39 & 136 & 461 \\
\hline & III & 29 & 71 & 0 & 100 & 16 & 14 & 13 & 7 & 29 & 79 \\
\hline \multirow{3}{*}{2004} & I & 30 & 48 & 0 & 78 & 16 & 37 & 66 & 20 & 56 & 195 \\
\hline & II & 108 & 186 & 2 & 296 & 40 & 84 & 168 & 35 & 106 & 433 \\
\hline & III & 34 & 24 & 0 & 58 & 2 & 3 & 36 & 6 & 20 & 67 \\
\hline \multirow{3}{*}{2005} & I & 61 & 85 & 0 & 146 & 23 & 37 & 47 & 22 & 109 & 238 \\
\hline & II & 198 & 309 & 2 & 509 & 78 & 109 & 160 & 71 & 211 & 629 \\
\hline & III & 20 & 32 & 0 & 52 & 18 & 11 & 24 & 8 & 15 & 76 \\
\hline \multirow{3}{*}{2006} & I & 40 & 83 & 0 & 123 & 18 & 18 & 48 & 4 & 54 & 142 \\
\hline & II & 173 & 311 & 0 & 484 & 50 & 40 & 121 & 28 & 107 & 346 \\
\hline & III & 48 & 45 & 0 & 93 & 10 & 3 & 17 & 2 & 14 & 46 \\
\hline \multirow{4}{*}{2007} & I & 41 & 93 & 0 & 134 & 9 & 19 & 43 & 26 & 54 & 151 \\
\hline & II & 104 & 243 & 0 & 347 & 21 & 43 & 133 & 41 & 128 & 366 \\
\hline & III & 16 & 44 & 0 & 60 & 2 & 21 & 33 & 10 & 27 & 93 \\
\hline & TOTAL & $\begin{array}{c}1434 \\
(35,5 \%)\end{array}$ & $\begin{array}{c}2593 \\
(64,3 \%)\end{array}$ & $8(0,2 \%)$ & 4035 & & & & & & \\
\hline
\end{tabular}


Branco, J.O. et al.

Table 4. Number of nests with young I, II, III and IV and juvenile S. leucogaster during the 2002 to 2007 reproductive seasons on the Moleques do Sul Islands.

\begin{tabular}{|c|c|c|c|c|c|c|c|c|c|c|c|c|c|c|}
\hline Years & & $\mathbf{J}$ & $\mathbf{F}$ & $\mathbf{M}$ & $\mathbf{A}$ & M & $\mathbf{J}$ & $\mathbf{J}$ & $\mathbf{A}$ & $\mathbf{S}$ & $\mathbf{O}$ & $\mathbf{N}$ & D & TOTAL \\
\hline \multirow{5}{*}{2002} & JI & 14 & 3 & 0 & 1 & 0 & 0 & - & 3 & 32 & 25 & 13 & 49 & 140 \\
\hline & JII & 11 & 43 & 1 & 0 & 0 & 0 & - & 1 & 11 & 63 & 33 & 17 & 180 \\
\hline & JIII & 59 & 55 & 29 & 30 & 0 & 0 & - & 0 & 4 & 10 & 104 & 119 & 410 \\
\hline & JIV & 33 & 35 & 7 & 15 & 0 & 0 & - & 0 & 0 & 5 & 0 & 25 & 120 \\
\hline & $\mathrm{J}$ & 16 & 20 & 69 & 51 & 186 & 10 & - & 10 & 4 & 12 & 1 & 4 & 383 \\
\hline \multirow{5}{*}{2003} & JI & 14 & 0 & 0 & 0 & 0 & 0 & 0 & 16 & 34 & 42 & 38 & - & 144 \\
\hline & JII & 16 & 7 & 0 & 2 & 0 & 0 & 0 & 15 & 28 & 26 & 25 & - & 119 \\
\hline & JIII & 34 & 48 & 22 & 4 & 0 & 0 & 0 & 0 & 2 & 20 & 59 & - & 189 \\
\hline & JIV & 16 & 16 & 5 & 10 & 1 & 0 & 5 & 2 & 0 & 0 & 10 & - & 65 \\
\hline & $\mathrm{J}$ & 41 & 17 & 40 & 36 & 40 & 29 & 9 & 9 & 8 & 15 & 4 & - & 248 \\
\hline \multirow{5}{*}{2004} & JI & 4 & 1 & 2 & 0 & 1 & 1 & - & 0 & 12 & 11 & 26 & - & 58 \\
\hline & JII & 10 & 3 & 0 & 1 & 2 & 0 & - & 0 & 62 & 27 & 19 & - & 124 \\
\hline & JIII & 83 & 10 & 13 & 5 & 1 & 0 & - & 0 & 12 & 55 & 91 & - & 270 \\
\hline & JIV & 16 & 7 & 5 & 8 & 2 & 0 & - & 0 & 0 & 0 & 23 & - & 61 \\
\hline & $\mathrm{J}$ & 15 & 14 & 44 & 27 & 28 & 11 & - & 0 & 5 & 6 & 32 & - & 182 \\
\hline \multirow{5}{*}{2005} & $\mathrm{JI}$ & 0 & 8 & 0 & 3 & 11 & 1 & 12 & 0 & 29 & 13 & 11 & 31 & 119 \\
\hline & JII & 0 & 26 & 0 & 9 & 5 & 3 & 3 & 0 & 53 & 11 & 14 & 33 & 157 \\
\hline & JIII & 0 & 54 & 0 & 24 & 21 & 4 & 4 & 0 & 10 & 55 & 33 & 26 & 231 \\
\hline & JIV & 0 & 42 & 0 & 8 & 9 & 1 & 0 & 0 & 1 & 4 & 18 & 18 & 101 \\
\hline & $\mathrm{J}$ & 0 & 72 & 0 & 86 & 81 & 16 & 4 & 0 & 9 & 18 & 17 & 32 & 335 \\
\hline \multirow{5}{*}{2006} & JI & 11 & 6 & 2 & 0 & 0 & 2 & 1 & 28 & 0 & 8 & 20 & - & 78 \\
\hline & JII & 10 & 10 & 8 & 1 & 0 & 1 & 0 & 3 & 0 & 16 & 12 & - & 61 \\
\hline & JIII & 67 & 38 & 29 & 18 & 6 & 1 & 1 & 3 & 0 & 13 & 10 & - & 186 \\
\hline & JIV & 5 & 12 & 5 & 3 & 1 & 1 & 2 & 0 & 0 & 0 & 5 & - & 34 \\
\hline & $\mathrm{J}$ & 29 & 20 & 30 & 31 & 22 & 5 & 11 & 7 & 0 & 13 & 7 & - & 175 \\
\hline \multirow{5}{*}{2007} & JI & 0 & 1 & 6 & 4 & 4 & 0 & - & 1 & 0 & 0 & 11 & 5 & 32 \\
\hline & JII & 0 & 17 & 15 & 17 & 5 & 3 & - & 4 & 0 & 0 & 15 & 7 & 83 \\
\hline & JIII & 0 & 48 & 35 & 27 & 19 & 5 & - & 1 & 0 & 0 & 66 & 8 & 209 \\
\hline & JIV & 0 & 11 & 15 & 7 & 3 & 8 & - & 1 & 0 & 0 & 24 & 8 & 77 \\
\hline & $\mathrm{J}$ & 0 & 28 & 37 & 35 & 32 & 42 & - & 10 & 0 & 0 & 14 & 11 & 209 \\
\hline
\end{tabular}

2005. Mellink et al. (2001) showed that the Brown Boobies that were on Isla San Jorge, Gulf of California, who usually remain in the colony after the breeding season, may abandon it by interrupting the breeding season due to the influence of weather conditions. So it seems that both hypotheses, abandonment and retention, may not be mutually exclusive, which would explain the occurrence of apparent abandonment of the colony by few individuals in 2002 and 2004 and permanence in the remaining three years of this study. It is not known if the Boobies that stay in the colonies outside the breeding season continue to defend their nesting territories, because this is one aspect of this species behavior which has not been studied.

The predominance of nests with one egg, recorded in the Moleques do Sul and Tamboretes Islands by Branco (2003, 2004), does not agree with the predominance of nests with two eggs found in this study. A higher proportion of nests with two eggs was reported by Alves et al. (2004a) and Coelho et al. (2004) on islands in Rio de Janeiro. Ostrowski et al. (2005) also found a higher proportion of nests with two eggs (67.6\%) on islands in Saudi Arabia. According to Drummond et al. (2003), the laying of two eggs in S. leucogaster is an adaptive strategy that ensures a greater chance of reproductive success for the species. The second chick to be born may be necessary to replace the senior one if it proves to be unviable or suffers predation. The presence of nests with three eggs is infrequent and may be related to intraspecific parasitism. In this case, the additional third egg may have been laid by a female stranger, not part of the couple, as pointed out by Baumgarten et al. (2001). Perhaps the predominance of nests with one egg recorded in years prior to this study by Branco $(2003,2004)$, may be due to variations in climate and to food availability.

The Brown Booby population, which nests on the Moleques do Sul Islands is in balance and does not undergo changes in population size during the reproductive years, indicating a favorable place for the conservation of the species. Long-term knowledge of demographic patterns and of colony occupation will enable us to monitor its life history. It will also be interesting to make an effort to develop behavioral studies to verify the presence of adults during the nonbreeding period, and to compare the reproductive success between the three sub-areas.

\section{Acknowledgments}

Thanks to the Universidade do Vale do Itajai (UNIVALI) for financial support, and to the Conselho Nacional de Desenvolvimento Científico e Tecnológico (CNPq), for a scientific productivity grant awarded to Dr Joaquim Olinto Branco. For FATMA (Fundação do Meio Ambiente de Santa Catarina) to the license for research and Field work. For all students that help in field work.

\section{References}

ALVES, V.S., SOARES, A.B.A., COUTO, G.S., RIBEIRO, A.B.B. \& EFE, M.A. 1997. Aves do Arquipélago dos Abrolhos, Bahia, Brasil. Ararajuba 5(2): 209-218. 
ALVES, V.S., SOARES, A.B.A. \& COUTO, G.S. 2004a. Aves marinhas e aquáticas das ilhas do litoral do Estado do Rio de Janeiro. In Aves marinhas e insulares brasileiras: Bioecologia e conservação (J.O. Branco, ed.). Univali, Itajaí, p.83-100.

ALVES, V.S., SOARES, A.B.A., COUTO, G.S., EFE, M.A. \& RIBEIRO, A.B.B. 2004b. Aves marinhas de Abrolhos. In Aves marinhas e insulares brasileiras: Bioecologia e conservação (J.O. Branco, ed.). Univali, Itajaí, p.213-232.

BAUMGARTEN, M.M., KOHLRAUSCH, A.B., MIYAKI, C.Y., FREITAS, T.R.O. \& ARAÚJO, A.M. 2001. DNA fingerprinting and parentage in Masked (Sula dactylatra) and Brown (S. leucogaster) Boobies. Ornitol. Neotrop. 12:319-326.

BEADELL, J.S., SCHREIBER, E.A., SCHREIBER, R.W., SCHENK, G.A \& DOHERTY JUNIOR, P.F. 2003. Survival of Brown Boobies (Sula leucogaster) at Johnston Atoll: A long-term study. Auk 120:811-817. http://dx.doi.org/10.1642/0004-8038(2003)120[0811:SOBBSL]2.0.CO;2

BEGE, L.A. \& PAULI, B.T. 1989. As aves nas ilhas Moleques do Sul - Santa Catarina: Aspectos da ecologia, etologia e anilhamento de aves marinhas. FATMA, Florianópolis.

BORSA, P., PANDOLFI, M., ANDRÉFOUET, S. \& BRETAGNOLLE, V. 2010. Breeding avifauna of the Chesterfield Islands, Coral Sea: Current population sizes, trends, and threats. Pac. Sci. 64(2):297-314. http:// dx.doi.org/10.2984/64.2.297

BOTH, R. \& FREITAS, T.O.R. 2004. Aves marinhas no arquipélago de São Pedro e São Paulo. In Aves marinhas e insulares brasileiras: Bioecologia e conservação (J.O. Branco, ed.). Univali, Itajaí, p.193-212.

BRANCO, J.O. 2003. Reprodução das aves marinhas nas ilhas costeiras de Santa Catarina, Brasil. Rev. Bras. Zool. 20(4):619-623. http://dx.doi. org/10.1590/S0101-81752003000400010

BRANCO, J.O. 2004. Aves marinhas das ilhas de Santa Catarina. In Aves marinhas e insulares brasileiras: Bioecologia e conservação (J.O. Branco, ed.). Univali, Itajaí, p.15-36.

BRANCO, J.O., FRACASSO, H.A.A., MACHADO, I.F., BOVENDORP, M.S. \& VERANI, J.R. 2005. Dieta de Sula leucogaster Broddaert (Sulidae, Aves) nas Ilhas Moleques do Sul, Florianópolis, SC. Rev. Bras. Zool. 22:1044-1049. http://dx.doi.org/10.1590/S010181752005000400033

BRANCO, J.O., FRACASSO, H.A.A., EFE, M.A., BOVENDORP, M.S., BERNARDES-JÚNIOR, J.J., MANOEL, F.C. \& EVANGELISTA, C.L. 2010. O atobá-pardo Sula leucogaster (Pelecaniformes: Sulidae) no Arquipélago de Moleques do Sul, Santa Catarina, Brasil. Rev. Bras. Ornitol. 18(3):222-227.

CAMPOS, F.P., PALUDO, D., FARIA, P.J. \& MARTUSCELLI, P. 2004. Aves insulares marinhas, residentes e migratórias, do litoral do Estado de São Paulo. In Aves marinhas e insulares brasileiras: Bioecologia e conservação (J.O. Branco, ed.). Univali, Itajaí, p.57-82.

CHAVES-CAMPOS, J. \& TORRES, J. 2002. Distribution of nests of the Brown Booby (Sula leucogaster) in relation to the inclination of terrain. Ornitol. Neotrop. 13:205-208.

COELHO, E.P.; ALVES, V.S.; SOARES, A.B.A.; COUTO, G.S.; EFE, M.A.; RIBEIRO, A.B.B.; VIELLIARD, J. \& GONZAGA, L.P. 2004. O Atobámarrom (sula Leucogaster) na ilha de Cabo Frio, Arraial do Cabo, Rio de Janeiro, Brasil. In Aves marinhas e insulares brasileiras: Bioecologia e conservação (J.O. Branco, ed.). Univali, Itajaí, p. 233-254
DORWARD, D.F. 1962. Comparative biology of the white and brown booby Sula spp of Ascension. Ibis 103b:174-220.

DRUMMOND, H., RODRIGUEZ, C., VALLARINO, A., VALDERRÁBANO, C., ROGEL, G.E., \& TOBÓN, E. 2003. Desperado siblings: uncontrollably agressive Junior chicks. Behav. Ecol. Sociobiol. 53:287-296.

GROSE, A.V., SCHULZE, B. \& CREMER, M.J. 2011. Registro de reprodução do atobá-pardo Sula leucogaster (Suliformes: Sulidae) em estrutura artificial no estuário da baía da Babitonga, Santa Catarina, Brasil. Rev. Bras. Ornitol. 19(4):541-544

KRUL, R. 2004. Aves marinhas costeiras do Paraná. In Aves marinhas e insulares brasileiras: Bioecologia e conservação (J.O. Branco, ed.). Univali, Itajaí, p.37-56.

LEWIS, S., SCHEIBER, E.A., DAUNT, F., SCHENK, G.A., ORR, K., ADAMS, A., WANLESS, S. \& HAMER, K.C. 2005. Sex-specific foraging behavior in tropical boobies: does size matter? Ibis 147:408-414. http://dx.doi.org/10.1111/j.1474-919x.2005.00428.x

MARCHANT, S. \& HIGGINS, C.J. 1990. Handbook of Australian, New Zealand and Antarctic birds. v. 1. Oxford University, Melbourne.

MARTINS, F.C. \& DIAS, M.M. 2003. Cuidado parental de Sula leucogaster (Boddaert) (Aves, Pelcaniformes, Sulidae) nas Ilhas dos Currais, Paraná, Brasil. Rev. Bras. Zool. 20(4):583-589. http://dx.doi.org/10.1590/S010181752003000400004

MELLINK, E., DOMÍNGUEZ, J. \& LUÉVANO, J. 2001. Diet of eastern pacific Brown Boobies Sula leucogaster brewsteri on Isla San Jorge, north-eastern Golf of California, and an april comparison with diets in the middle Gulf of California. Mar. Ornithol. 29:23-28.

NELSON, J.B. 1978. The Sulidae: Gannets and Boobies. Oxford University, Oxford.

NEVES, T.S. 1999. As aves do Parque Estadual Marinho da Laje de Santos. Instituto Florestal, São Paulo.

OSTROWSKI, S., SHOBRAK, M., AL-BOUG, A., KHOJA, A. \& BEDIN, E. 2005. The breeding avifauna of the Umm Al-Qamari Islands protected area, Saudi Arabia. Sandgrouse 27(1):53-62.

POWLESLAND, R.G. \& POWLESLAND, M.H. 1993. Seabirds found dead on New Zealand beaches in 1991, and a review of Morus and Sula species recoveries, 1943 to 1991. Notornis 40(4):233-245.

SCHULZ-NETO, A. 2004a. Aves insulares do arquipélago de Fernando de Noronha. In Aves marinhas e insulares brasileiras: Bioecologia e conservação (J.O. Branco, ed.). Univali, Itajaí, p.147-168.

SCHULZ-NETO, A. 2004b. Aves marinhas do Atol das Rocas. In Aves marinhas e insulares brasileiras: Bioecologia e conservação (J.O. Branco, ed.). Univali, Itajaí, p.169-192.

SCHULER, L.M. \& PINHEIRO, H.T. 2009. Estrutura populacional e repertório comportamental de Sula leucogaster (Sulidae) . em um sítio de repouso no sudeste do Brasil. Rev. Bras. Ornit. 17(2):96-101.

SICK, H. 1997. Ornitologia brasileira. Nova Fronteira, Rio de Janeiro.

SOKAL, R.R. \& ROHLF, F.J. 1969. Biometry, the principles and practices of statistics in biological research. W. H. Freeman and Co., San Francisco, 776p.

TERSHY, B.R. \& CROLL, D.A. 2000. Parental investment, adult sex ratios, and sexual selection in a socially monogamous seabird. Behav. Ecol. Sociobiol. 48:52-60. http://dx.doi.org/10.1007/s002650000182 